\title{
Kategoria braku odpowiedzi w świadomości rozmówców
}

\section{Perception of lack of answer in social consciousness}

\author{
Włodzimierz Lapis \\ Instytut Językoznawstwa, Uniwersytet im. Adama Mickiewicza \\ ul. Międzychodzka 5, 60-371 Poznań \\ włodzimierz@lapis.pl
}

\begin{abstract}
The article presents the analysis of utterances found on Polish Internet sites concerning lack of reply: what is it, what does it tell us, and what logical value does it have? The result of this work is the introduction of reliable criteria, enabling us to give correct replies in a given situation.

\section{Wprowadzenie}

W poniższym tekście proponuje się dokonanie analizy zjawiska braku odpowiedzi (nieudzielenie jej) w trakcie procesu komunikacyjnego. Ponieważ często można się spotykać $\mathrm{z}$ tego typu sytuacja, celowe jest zbadanie jej w kontekście efektywności komunikacji.

Czy brak odpowiedzi jest odpowiedzią? Jeśli nie - to dlaczego można przyjąć, że nią nie jest? Jeśli tak - to jakiego rodzaju jest to odpowiedź i o czym ona świadczy? Jak brak odpowiedzi przyjmowany jest przez odbiorców i jak funkcjonuje on w świadomości społecznej? Jaka jest emocjonalna reakcja na brak odpowiedzi i jaką ma on wartość logiczną w poszczególnych dziedzinach działalności ludzkiej? (tj. np. czy oznacza akceptację, czy też jej brak?).

$\mathrm{Na}$ te i pokrewne im pytania postarano się odpowiedzieć w niniejszym artykule. Materiał do badań zebrany został z zasobów polskiego Internetu za pomocą wyszukiwarki www.szukacz.pl (w listopadzie 2003 r.). Tabela 1 podaje, w oparciu o jakie zapytania internetowe (frazy wpisywane w oknie wyszukiwarki internetowej), ile poprawnych wyników zostało wyszukanych, a następnie wziętych do dalszej analizy. Poprzez wyniki rozumie się tutaj stronę internetową, zawierająca frazę zadaną w zapytaniu internetowym. Z kolei, poprzez wynik poprawny przyjmuje się taki, w którym całe zapytanie internetowe znajduje się w jednym zdaniu prostym. Dla rozważanych tu celów tylko takie wyniki moga być przydatne. W przeciwnym bowiem przypadku (np. w wyniku: 16.04 .00 - ciagle brak odpowiedzi; nie wydaje mi się, że chodzi o drzewo genealogiczne ${ }^{[1] 1}$ ) poszczególne jego słowa zapytania brak odpowiedzi nie nie są bezpośrednio połączone semantycznie.
\end{abstract}

\footnotetext{
${ }^{1} \mathrm{~W}$ ten sposób w artykule zaznaczono odwołania do stron internetowych, których adresy podano zaraz za bibliografią
} 
Zestawienie liczby analizowanych wyników poszczególnych zapytań internetowych

\begin{tabular}{|l|c|c|}
\hline \multicolumn{1}{|c|}{ Zapytanie internetowe } & liczba wyników poprawnych & W tym pytań \\
\hline brak odpowiedzi jest & 154 & 2 \\
\hline brak odpowiedzi oznacza & 41 & 1 \\
\hline brak odpowiedzi nie & 27 & \\
\hline RAZEM & 222 & 3 \\
\hline
\end{tabular}

W sumie przeanalizowano więc 222 wyniki, wśród których 3 były pytaniami.

W całym artykule:

$>$ kursywą podawane są cytowane wypowiedzi (lub ich fragmenty),

$>$ w nawiasach (przy cytatach) ujmowane są niezbędne dopowiedzenia lub wyjaśnienia,

$>$ podkreśleniem zaznaczono tę część cytatu, która potem jest bardziej szczegółowo omawiana.

Jedna $\mathrm{z}$ wypowiedzi zaczerpnięta $\mathrm{z}$ polskiego Internetu (spoza zakresu wypowiedzi poddanych tu badaniom) jest postaci: brak odpowiedzi to także fajne rozwiazanie, bo nie znaczy nic ${ }^{[2]}$. Warto sprawdzić czy - w świetle analizowanych tu wypowiedzi rzeczywiście tak jest. Wyniki badań w tym zakresie podano w poniższych paragrafach.

\section{$2 \quad$ Czym jest brak odpowiedzi?}

\subsection{Czy brak odpowiedzi jest odpowiedzią?}

$\mathrm{Na}$ jednej ze stron polskiego Internetu można spotkać się z pytaniem (1 raz): czy brak odpowiedzi jest też odpowiedziq? ${ }^{[2]}$, i zaraz z odpowiedzią (przytoczono jej sens, a nie literalne brzmienie): tak, bo zawsze ją wysyłamy, a jeśli jej nie otrzymaliśmy (co odczytujemy jako brak odpowiedzi), to tylko dlatego, że zaginęła gdzieś po drodze...

Bezwarunkowe, bezpośrednie stwierdzenie, że brak odpowiedzi jest odpowiedzią, w zasobach polskiego Internetu występuje 50 razy, przy czym zawsze przed słowem odpowiedziq z dodanym słowem:

$>t e \dot{z}-40$ razy (w tym 3 razy zaczynającym się od słów weź pod uwagę, że, co nadaje jej mentorski charakter),

$>$ także -6 razy (w tym 1 raz poprzedzonym stwierdzeniem Za bardzo nie wierzę, że jesteś $w$ Warszawie. Ale cóż, ... , co oznacza, że osoba wypowiadająca te słowa daje do zrozumienia, że wie, że jest wprowadzona w błąd przez swego rozmówcę i 1 raz $\mathrm{z}$ dopowiedzeniem $i$ ważna wskazówkq dzisiaj dla postów SLD (...), co oznacza, że ów brak odpowiedzi przez posłów SLD został jednoznacznie odczytany),

$>$ również -4 razy, w tym:

○ $1 \mathrm{raz}$ - jako stwierdzenie poprzedzone wyrażeniem: Należy uznać, ̇̇e (co oznacza, że jest to dość powierzchowny wywód),

- 1 raz w kontekście: Na odpowiedź oczekiwałem bezskutecznie przez trzy miesiqce. Brak odpowiedzi jest jednak również odpowiedziq. Przykre. (co wskazuje na brak kultury nieodpowiadającej strony).

Dodatkowo w polskim Internecie 1 raz występuje sformułowanie w swej treści wyraźnie ograniczone do opisywanej sytuacji: VOTH nie zajmuje stanowiska $w$ kontrowersyjnych sprawach. (...) Osobiście uważam, że brak odpowiedzi jest $\underline{w}$ tym przypadku jednocześnie odpowiedziq. ${ }^{[3]}$ Użyte tu wyrażenie $w$ tym przypadku sugeruje, że nie zawsze tak musi być (tj. że brak odpowiedzi może nie być odpowiedzia). Sytuacja, o której tu mowa, to kontrowersyjna sprawa, skąd wnosimy, że to właśnie wtedy unika się podawania odpowiedzi, przyjmując takie zachowanie za naturalne. 
W polskim Internecie występuje jedna wypowiedź stwierdzającą, że brak odpowiedzi nie jest odpowiedzią:

Religie (...) - to wynik (...) buntu przeciw pojawiajacym się prostym pytaniom, a raczej

przeciwko brakowi na nie logicznych odpowiedzi. (...) Brak odpowiedzi nie jest $w$ tym

przypadku odpowiedziq, więc należało znaleźć wyjście z tej kłopotliwej sytuacji. ${ }^{[4]}$

Odnośnie braku wypowiedzi (czym ona nie jest), wypowiedź ta nie daje jednoznacznego rozwiązania. Stosuje się bowiem tylko do tej sytuacji (ze względu na słowa $w$ tym przypadku). Ponadto odpowiedź znaczy tu „rozwiązanie”, ma więc znaczenie poboczne do rozważanego w tym artykule.

W niniejszym paragrafie jest więc razem 51 stwierdzeń, że brak odpowiedzi jest odpowiedzią (plus jedno podane na samym początku tego paragrafu, ale nie jako stwierdzenie w takiej postaci, lecz jako odpowiedź na tak postawione pytanie), przy czym w części z nich występują pewne dopowiedzenia, które pozwalają wnioskować:

$>$ jakiego typu jest to odpowiedź,

$>$ że rozmówca nieudzielający odpowiedzi postępuje niekulturalnie,

$>$ że jest odpowiedzią, ale jedynie w odniesieniu do opisywanej sytuacji.

Tylko jeden raz występuje stwierdzenie, że brak odpowiedzi nie jest odpowiedzią, jednak nie w sposób bezwarunkowy (bo z dopowiedzeniem $w$ tym przypadku) i na dodatek $\mathrm{w}$ innym znaczeniu wyrazu odpowiedź.

\subsection{Jakiego typu odpowiedzią jest brak odpowiedzi?}

W polskich zasobach Internetu znajduje się następujący dowcip, w którym podaje się, że do izby, w której należało milczeć, niespodziewanie wchodzi nieproszony gość i zadaje pytania gospodarzom. W dowcipie tym występują 3 wypowiedzi, że brak odpowiedzi jest pozytywną odpowiedzią:

> Szybki Bill pomyślat - hmmm brak odpowiedzi jest pozytywna odpowiedziq. - $1 \mathrm{raz}$;

> Szybki Bill pomyślat - hmmm brak odpowiedzi jest odpowiedziq pozytywnq. - $1 \mathrm{raz}$;

$>$ Wiedzac, że brak odpowiedzi jest odpowiedzia pozytywna, (...). - 1 raz.

Gość - w związku z milczeniem gospodarzy i w oparciu o własne przemyślenia podejmował określone działania, które wcale nie były po myśli domowników (humor sytuacyjny). Przykład ten ukazuje, że interpretacja milczenia (w tej sytuacji: braku odpowiedzi) może być różna (tu: przez domowników i ich gościa), co z kolei może prowadzić do konfliktów. Ponadto wynika stąd, że w danych okolicznościach szybko przechodzi się od myślenia do przekonania, że brak odpowiedzi jest odpowiedzią pozytywną (w omawianym przykładzie za każdym razem taka jest właśnie interpretacja braku odpowiedzi).

W poniższym tekście (w polskich zasobach Internetu występuje on 4 razy) występuje stwierdzenie, że brak odpowiedzi jest dobra odpowiedzią:

Polecenia w systemie Linux charakteryzuja się dwiema cechami:

1) Większość poleceń zawiera bardzo duża ilość opcji. (...);

2) „Brak odpowiedzi jest dobra odpowiedziq” - większość poleceń Linux'a wyświetla bardzo skapq ilość danych wynikowych. Brak odpowiedzi należy traktować jako poprawne wykonanie komendy. Dla przykładu polecenie wyświetlenia zawartości pustego katalogu nie spowoduje wyświetlenia żadnych informacji. ${ }^{[5]}$

Fakt, że odpowiedź jest poprawna, może wiele znaczyć: na przykład, że jest pozytywna, zgodna z czyimś oczekiwaniem, trafna, jak najbardziej na miejscu. Trudno więc zakwalifikować tak określoną odpowiedź. W tym jednak przypadku najwyraźniej chodzi o kategorię ,poprawna, jak najbardziej na miejscu”. Określenie czy chodzi o odpowiedź pozytywną (na „tak”) czy negatywną (na „nie”) nie jest więc tu możliwe. 
W polskim Internecie 5 razy występuje stwierdzenie: Kandydatów proszę o precyzyjne, pozbawione demagogii $i$ podręcznikowych ogólników odpowiedzi. Brak odpowiedzi jest odpowiedziq najgorsza. Odnoszące się do odpowiedzi sformułowanie najgorsza oznacza tu, że jest to odpowiedź „najmniej pożądana”. Znowu nie jest więc odpowiedzią ani na „tak” ani na „nie”.

W końcu, w polskim Internecie, 2 razy na blogu występuje wypowiedź: Brak odpowiedzi jest odpowiedziq niespodziewana, inna, nieprzewidziana, nie do poradzenia, określenia. W tym przypadku również nie jest to wypowiedź, która by określała brak odpowiedzi na „tak” czy na „nie”. Wskazuje jednak na kłopoty i utrudnienia wynikające z jej stosowania.

Sumując, 11 razy (3 ostatnie sytuacje) nie wiadomo, jakiego typu jest to odpowiedź - na „tak” czy na „nie”, a w 3 przypadkach (pierwsza sytuacja), mimo że stwierdzenia te są odpowiedziami na „tak”, to jednak kryje się za nimi odpowiedź na „nie” (tak by normalnie odpowiedzieli domownicy, gdyby mogli mówić). Wynika stąd, że w polskich zasobach Internetu - na dobrą sprawę (tj. ze względu na przytoczoną tu interpretację pierwszej sytuacji) - nie ma bezpośredniej odpowiedzi na pytanie, czy formalny brak odpowiedzi jest odpowiedzią na „tak” czy na „nie”.

\section{Brak odpowiedzi a wewnętrzna postawa człowieka}

\subsection{Brak odpowiedzi oddający stan ducha niedoszlego odbiorcy odpowiedzi}

Ponieważ - jak wyżej podano - trudno jest orzec, co oznacza brak odpowiedzi, zatem jej brak u osoby jej oczekującej często wywołuje określone stany emocjonalne. Oddają to poniższe wypowiedzi zaczerpnięte z polskiego Internetu:

> Brak odpowiedzi jest cierpieniem, ciagłe poszukiwania, rozterki ... - 1 raz;

$>$ Brak odpowiedzi jest katorga, wielka pustka, która nie zostaje wypetniona - 1 raz;

$>$ Brak odpowiedzi jest odpowiedziq niespodziewana, inna, nieprzewidziana, nie do poradzenia, określenia - 2 razy;

$>$ brak odpowiedzi nie podziałał na mnie uspokajajaco - 2 razy;

> brak odpowiedzi jest jak wyrok... (odpowiedź na pytanie: „kiedy to wszystko się wreszcie skończy?") - 3 razy;

$>$ brak odpowiedzi nie zabiera tak moich nocy rozmyślań jak jedno pytanie do samej siebie .. (tj. zbytnio mnie nie intryguje) - 1 raz.

$\mathrm{W}$ tych 10 wystapieniach podano, że brak odpowiedzi spowodował negatywne odczucia $\mathrm{u}$ osoby jej oczekującej, przy czym tylko w jednym przypadku (ostatnim), że wcale nie są one znaczne (w przeciwieństwie do poprzednich wypowiedzi, które są bardziej kategoryczne).

\subsection{Wypowiedzi świadczące o braku kultury niedoszlego nadawcy odpowiedzi}

W polskich zasobach Internetu wystęują też wypowiedzi, odnoszące się do kultury osób, które nie udzielają odpowiedzi:

$>$ Brak odpowiedzi jest przejawem chamstwa i lekceważenia wyborcy; niestety, ten brak odpowiedzi jest reguta (...) - 5 razy;

$>$ Należy odpowiadać na wszystkie e-mail'e od klientów, gdyż brak odpowiedzi jest równoznaczny z lekceważeniem - 52 razy;

$>$ Brak odpowiedzi oznacza, że nie wie jak nas powkurzać - 1 raz;

$>$ Brak odpowiedzi jest wymowny: "Świetnie, bo bez ciebie". (w przypadku zapytania o zdrowie i o to, ,jak leci”...) - 2 razy;

$>$ Brak odpowiedzi jest, niestety, rzeczq dosyć powszechna (przy staraniu się o pracę) - 2 razy (wypowiedź ta znalazła się tu za sprawą występującego w niej słowa niestety).

Tak więc w polskich zasobach Internetu w sumie jest 5 typów wypowiedzi (62 wystąpienia) świadczących o tym, że brak odpowiedzi jest przejawem braku kultury. 


\section{Brak odpowiedzi w różnych dziedzinach}

$\mathrm{W}$ polskich zasobach Internetu w prosty i jednoznaczny sposób można wydzielić wypowiedzi odnoszące się do braku odpowiedzi w poszczególnych - wymienionych poniżej - dziedzinach działalności ludzkiej.

\subsection{Wypowiedzi związane $z$ rekrutacją do nauki i do pracy}

W polskim Internecie występują wypowiedzi na temat braku odpowiedzi przy staraniu się o pracę lub o podjęcie nauki, co ma miejsce ze strony osoby czy instytucji, rekrutującej:

Brak odpowiedzi jest

$>$ niestety, rzeczq dosyć powszechnq (przy staraniu się o pracę, $\mathrm{z}$ dopowiedzeniem, że jednak ma się prawo do jej uzyskania, zatem można dzwonić i pytać o wynik rozmowy kwalifikacyjnej) - 2 razy;

$>$ sygnałem braku zainteresowania (przy staraniu się o pracę) - 2 razy;

$>$ równoznaczny $z$ niezakwalifikowaniem kandydata (pozostałe osoby będą powiadomione o dalszym przebiegu postępowania rekrutacyjnego do pracy) - 3 razy.

Brak odpowiedzi oznacza

$>$ umieszczenie ankiety $w$ rezerwie kadrowej (wypowiedź dotyczy braku odpowiedzi na złożoną aplikację, jest eufemistycznym stwierdzeniem nieprzyjęcia do pracy) - 1 raz;

$>$ odpowiedź negatywna (zdanie poprzedzone zdaniem: Dzisiaj się wyda, czy chca mnie w Oceanicu, co w sumie oznacza, że musiało to być wcześniej ustalone) $1 \mathrm{raz}$

> niezakwalifikowanie (jest to dopowiedzenie do zdania: Osoby, które zakwalifikuja się na dany kurs, powiadomimy osobnym pismem) - 2 razy.

W sumie jest tu 11 wypowiedzi ( 6 typów). Pierwsze 5 typów (9 wypowiedzi) dotyczy starania się o pracę, a dwie wypowiedzi ostatniego typu odnoszą się do starania się o przyjęcie na kurs. Cztery wypowiedzi (pierwsze 2 typy) zaczerpnięte są z porad jak się starać o pracę; kolejne cztery wypowiedzi (tj. następne 2 typy) - to informacje ze strony potencjalnych pracodawców; wypowiedź piątego typu oznacza, że brak odpowiedzi jest odpowiedzią negatywną tylko dlatego, że w tej konkretnej sytuacji tak zostało ustalone (podobnie jak w przypadku 2 wypowiedzi ostatniego typu, tym razem jednak w odniesieniu do starania się o przyjęcie na kurs). Tak więc, w każdej z tych sytuacji, brak odpowiedzi oznacza niezakwalifikowanie.

W polskich zasobach Internetu istnieje jeszcze jedna wypowiedź tycząca się rekrutacji do pracy, w której jednak brak odpowiedzi jest ze strony osoby rekrutowanej: $W$ trakcie rozmowy kwalifikacyjnej często pada pytanie o przykład pracy zespołowej. Brak odpowiedzi jest $w$ takiej sytuacji równoznaczny $z$ dyskwalifikacja. W świetle tej wypowiedzi, przy staraniu się o pracę, brak odpowiedzi (tj. milczenie) po stronie osoby rekrutowanej, także oznacza jej niezakwalifikowanie.

\subsection{Wypowiedzi dotyczące pracy komputera}

Niektóre z zebranych wypowiedzi odnoszą się do pracy komputera. Jest ich 25:

$>$ brak odpowiedzi jest dobra odpowiedziq (odnośnie poleceń Linux'a) - 4 razy (wypowiedź ta pojawiła już się w drugim paragrafie);

$>$ brak odpowiedzi oznacza brak wyników (w wyszukiwarce) - 10 razy;

$>$ brak odpowiedzi oznacza, że zostat podany btędny adres zwrotny lub serwer pocztowy/konto sq zablokowane - 2 razy;

$>$ brak odpowiedzi oznacza, że testowany system nie jest sprawny - 6 razy; 
> Instrukcja ping korzysta z protokołu ICMP, gdy kilka razy brak odpowiedzi wówczas brak odpowiedzi oznacza, że stacja nie jest osiagalna - 1 raz;

> brak odpowiedzi oznacza brak aktywnego hosta - 1 raz;

$>w$ przeciwnym wypadku host zdalny zignoruje zadany pakiet. Metoda ta nie daje jednoznacznych rezultatów, ponieważ brak odpowiedzi nie jest równoznaczny $z$ trafieniem $w$ zamknięty port -1 raz.

Wszystkie powyższe stwierdzenia określają co oznacza (czy też czym jest) brak odpowiedzi. Nie zawsze są one ścisłe - często mogą wskazywać na sytuacje alternatywne. Zawsze jednak brak odpowiedzi coś znaczy (chociażby powoduje odrzucenie pewnych sytuacji). W informatyce, jako nauce ścisłej, jest to konieczne. Tu po prostu nie ma miejsca na niedomówienia.

\subsection{Brak odpowiedzi w ustawodawstwie i w postępowaniu prawnym}

$\mathrm{W}$ polskim Internecie, $\mathrm{w}$ odniesieniu do sfery sądownictwa, pojawiają się 2 następujące wypowiedzi (w sumie 3 razy):

> Brak odpowiedzi jest równoznaczny z odmowq udzielenia informacji i uzasadnia skargę do NSA - potwierdzit sędzia - $1 \mathrm{raz}$

$>$ Sędzia nie uznat, że brak odpowiedzi jest tożsamy z nieudzieleniem informacji- 2 razy

Obie te sytuacje stwierdzają: brak odpowiedzi, to brak informacji (i nic więcej). W sądzie nie dochodzi więc do jakiejkolwiek nadinterpretacji braku odpowiedzi.

$\mathrm{Z}$ kolei $\mathrm{w}$ dziedzinie prawodawstwa $\mathrm{w}$ polskim Internecie występują następujące 2 wypowiedzi:

$>$ Dlatego (bo wymagane jest współdziałanie stron) brak odpowiedzi nie może być uznany za uzgodnienie sald (w dziedzinie rachunkowości) - 1 raz;

$>$ Dyrektywa Parlamentu Europejskiego i Rady Unii Europejskiej. (...) ART. 9 Państwa Członkowskie (UE) podejmq niezbędne działania w kierunku: (...) zwolnienia konsumenta z dokonywania jakichkolwiek platności w przypadkach dostaw nie zamówionych, przy czym brak odpowiedzi nie oznacza zgody. - 1 raz.

Oba te przypadki oznaczaja, że brak odpowiedzi nie oznacza zgody.

\subsection{Brak odpowiedzi przy punktacji}

W polskim Internecie znalazły się 3 stosowne typy wypowiedzi:

> jak ci trzasne zestaw pytań, to .. heh oczywiście za btędna lub brak odpowiedzi jest przewidziana kara - 1 raz;

$>$ brak odpowiedzi oznacza zero punktów (za dane pytanie na teście) - 6 razy;

$>w$ teście będzie można dostać 2 punkty. Za nieprawidlowa - minus 1 punkt. Brak odpowiedzi nie będzie $w$ ogóle oceniany - 1 raz.

Tak więc brak odpowiedzi oznacza tu zero punktów lub punkty ujemne.

\section{Wypowiedzi na ,tak" i na ,nie"}

W polskim Internecie 1 raz występuje wypowiedź: Czy brak odpowiedzi oznacza nieme przytaknięcie? Podziel się doświadczeniami, to bardzo interesujace. Warto więc przebadać wypowiedzi o jednoznacznym znaczeniu braku odpowiedzi.

\subsection{Wypowiedzi na ,tak”}

W drugim paragrafie przy omawianiu dowcipu podano, że 3 razy występuje w nim stwierdzenie, że brak odpowiedzi jest odpowiedzią pozytywną. Analogiczna sytuacja jest również w innym dowcipie zamieszczonym w polskim Internecie. Także w nim 3 wypowiedzi świadczą, że brak odpowiedzi oznacza zgodę:

> Uznat że brak odpowiedzi oznacza zgodę. - 1 raz;

$>$ Znowu brak reakcji. Więc jak zapytat - tak zrobit. - 1 raz;

$>$ Znowu cisza. Rozochocony brakiem sprzeciwu - zrobil co swoje. - 1 raz. 
W niniejszym artykule rozważa się jedynie pierwszą z nich, jako że tylko ona zawiera w sobie frazę - jedno z trzech rozpatrywanych zapytań internetowych.

W polskim Internecie występują jeszcze następujące wypowiedzi, w których brak odpowiedzi świadczy na „tak” (tj. jest poczytywany jako akceptacja, potwierdzenie):

$>$ No cóż, uznatem, że brak odpowiedzi jest zgoda!! (gdy pytano się o zgodę na zamieszczenie materiałów z innych stron WWW na swojej stronie) - 1 raz;

$>$ (Wypowiedzcie się na dany temat!) Brak odpowiedzi jest równoznaczny ze zgoda - 1 raz;

$>$ Brak odpowiedzi jest przyznaniem, że to prawda - 4 razy;

$>$ A fundator uznat, że brak odpowiedzi nie jest stanowczq odmowq i rozpoczat budowe - 1 raz.

W sumie jest tu więc 11 wypowiedzi ( $3 \mathrm{z}$ pierwszego dowcipu, $1 \mathrm{z}$ tu omówionego i 7 wypowiedzi z powyższych 4 punktów).

\subsection{Wypowiedzi na ,nie"}

W polskim Internecie występują jedynie 2 wypowiedzi (w sumie 4 razy) świadczące, że: brak odpowiedzi jest odpowiedzią na „nie”:

$>$ Zaznaczyliśmy, że brak odpowiedzi oznacza brak potrzeby $w$ otrzymywaniu biuletynu. Wystaliśmy listy do ponad 18 odbiorców. - 1 raz;

$>$ brak odpowiedzi nie jest odpowiedzia pozytywnq - 3 razy.

\section{Przyczyny braku odpowiedzi}

\subsection{Odpowiedzi odnoszące się do niemożności udzielenia odpowiedzi}

$\mathrm{W}$ polskim Internecie są 3 typy wypowiedzi, odnoszące się do nieczytania pytania (w sumie występują 7 razy):

$>$ (szef mógł nakazać milczenie) Tak więc brak odpowiedzi nie znaczy wcale, że rzecznik tego nie czytat. - 5 razy;

> brak odpowiedzi nie oznacza, że nikt pytania nie czytat.. - 1 raz;

$>$ dla niego brak odpowiedzi oznacza, że nikt pytania nie czytat - 1 raz.

Ponadto w polskim Internecie odnaleziono jeszcze 4 następujące typy wypowiedzi (występują w sumie 6 razy):

$>$ Brak odpowiedzi nie oznacza rzecz jasna, że to pytanie nie jest stawiane (co może oznaczać, że pytanie nie było czytane, jak i że interlokutor po prostu nie chce odpowiadać) $-1 \mathrm{raz}$

$>$ brak odpowiedzi nie oznacza złej woli grupowiczów. Może oznaczać, że nikt nie zna odpowiedzi -3 razy;

$>$ (ktoś) ten sam post ponawia kilka razy, jak by nie rozumiat iż brak odpowiedzi oznacza tylko jedno. (tu z kontekstu wynika rzecz jasna, że nikt nie zna odpowiedzi) - 1 raz;

$>$ Brak odpowiedzi oznacza iż korespondencja nie dotarła do nas - 1 raz.

Spośród przytoczonych tu 7 typów wypowiedzi:

$>$ pierwsze 5 zawiera sformułowanie: brak odpowiedzi nie jest / nie oznacza (ostatnie z nich dodatkowo niesie informację, co w takiej sytuacji może oznaczać) - w sumie 11 razy,

$>$ ostatnie 2 zawierają sformułowanie: brak odpowiedzi oznacza - w sumie 2 razy.

Mimo że większość z przedstawionych tu wypowiedzi podaje, iż brak odpowiedzi czegoś nie znaczy (czy nie oznacza), to jednak z każdej z nich wynika, że brak możliwości udzielenia odpowiedzi zawsze o czymś świadczy, coś oznacza.

\subsection{Inne przyczyny braku odpowiedzi}

W polskim Internecie 1 raz występujące pytanie: Czy brak odpowiedzi jest przyczyna braku czasu, czy niewiedzy? (prosze o odp.). Pytanie to jest źle sformułowane, ponieważ (jak wynika $\mathrm{z}$ semantyki użytych w nim słów) zadająca je osoba chciała dowiedzieć się nastepstwem czego jest brak odpowiedzi: braku czasu, czy niewiedzy?,

a więc:

co jest powodem braku odpowiedzi: braku czasu, czy niewiedza? 
(czyli odwrotnie niż to wyraziła syntaktyką tego zdania).

W polskim Internecie mamy podane jeszcze zaledwie 2 sytuacje obrazujące, czym może być spowodowany brak odpowiedzi (jego przyczyny, powody):

$>$ podobno brak odpowiedzi jest spowodowany nieopracowaniem przez Ministerstwo Gospodarki Kryterium ... - 1 raz;

$>$ brak odpowiedzi jest chyba jedyna możliwa konkluzja (tj. następstwem następującej sytuacji): nie ma sposobu na realizacje ... - 1 raz.

W każdej z tych 3 wypowiedzi podany jest więc konkretny powód braku odpowiedzi: brak czasu, niewiedza, brak odpowiedniego opracowania czy też sposobu na realizację zadania.

\subsection{Inne skutki braku odpowiedzi}

W polskim Internecie znalazły się następujące 4 wypowiedzi (w sumie 5 razy) świadczące o tym, co jest następstwem braku odpowiedzi (lub równoważnie: czego przyczyną jest brak odpowiedzi):

$>$ brak odpowiedzi jest przyczynq zaniechania tego pomystu - 1 raz;

> Pytania dziennikarzy (...) pozostawaty bez odpowiedzi. Brak odpowiedzi oznacza zaś, że informacje te nie znajda sie $w$ mediach $-1 \mathrm{raz}$

> Brak odpowiedzi oznacza postój /w jakiejś planszowej grze językowej/ - 2 razy;

$>$ Iwanow szuka odpowiedzi na te pytania, gdyż wie, że brak odpowiedzi oznacza dla niego, że stanie się martwy jeszcze za życia - 1 raz.

\subsection{Czego nie oznacza brak odpowiedzi?}

W polskim Internecie znalazły się również 2 wypowiedzi (w sumie 3 razy) określające, czego nie oznacza brak odpowiedzi:

> Brak odpowiedzi nie oznacza przerwy urlopowej, po prostu księga gości nie stuży do prowadzenia korespondencji - $1 \mathrm{raz}$

$>$ dla niego (człowieka, który za przeciwnika ma dyletanta) brak odpowiedzi (najlepszej) nie oznacza żadnej kary (w japońskiej grze w go) - 2 razy.

\section{Podsumowanie}

$\mathrm{W}$ niniejszym artykule, na podstawie analizy informacji zawartych w polskich zasobach Internetu, najpierw wywnioskowano, że brak odpowiedzi jest odpowiedzią (ponad 50 odpowiedzi potwierdzających ten sąd, przy jednej przeciwnej, jednak z zastrzeżeniem że i tak stosuje się jedynie do omawianej sytuacji). Następnie zbadano, jakiego typu jest to odpowiedź i wywnioskowano, że: najgorsza, dobra, niespodziewana. Nawet gdy 3 razy pojawiło się stwierdzenie, że brak odpowiedzi jest pozytywną odpowiedzią, to i tak okazywało się, że wcale nie jest to jednoznaczne. Tak więc w polskim Internecie nie ma bezpośredniej odpowiedzi na pytanie czy brak odpowiedzi jest odpowiedzią na „tak”, czy też na „nie”.

Następnie 10 razy było podane, że brak odpowiedzi powoduje negatywne odczucia u osoby jej oczekującej, a aż 62 razy (co stanowi prawie $30 \%$ wszystkich przeanalizowanych wypowiedzi), że postawa taka świadczy o braku kultury niedoszłego nadawcy odpowiedzi.

Badano też, co oznacza brak odpowiedzi w poszczególnych dziedzinach działalności ludzkiej, i wnioskowano, że:

$>$ brak odpowiedzi przy staraniu się o pracę czy o przyjęcie na kurs zawsze oznacza niezakwalifikowanie (12 wypowiedzi);

$>$ brak odpowiedzi $\mathrm{w}$ informatyce $(25$ wypowiedzi) zawsze jest jednoznacznie interpretowany;

$>$ w sądownictwie (3 wypowiedzi) brak odpowiedzi, to brak informacji, a w prawodawstwie (2 wypowiedzi) brak odpowiedzi nie oznacza zgody;

$>$ brak odpowiedzi przy punktacji (8 wypowiedzi) zawsze oznacza zero punktów lub punkty ujemne.

W pozostałych przypadkach w polskich zasobach Internetu jest 5 wypowiedzi na "tak" (oznaczające potwierdzenie, akceptację) i 4 na „nie” (oznaczające rezygnację, brak akceptacji). 
Analizowano również wypowiedzi, odnoszące się do niemożności udzielenia odpowiedzi (13 razy). Zawsze okazywało się, że jest ona czymś spowodowana, często nie tym, czego można by się spodziewać. Tak więc brak odpowiedzi, przy braku możliwości udzielenia jej, zawsze o czymś świadczy, coś oznacza. Dodatkowo 2 wypowiedzi bezpośrednio wskazywały, czym jest on spowodowany, 5 - do jakich konsekwencji prowadzi, a 3 - czego nie oznacza.

\section{Wnioski}

W oparciu o powyższe rozważania można dojść do wniosku, że choć wśród przeanalizowanych wypowiedzi występują różne interpretacje braku odpowiedzi, to jednak po ich odpowiednim pogrupowaniu odpowiedź na pytanie: co oznacza (lub czym jest) brak odpowiedzi w konkretnym przypadku (poprzez odniesienie do określonej kategorii) staje się prosta i jednoznaczna.

Ponadto, w jednej $\mathrm{z}$ wypowiedzi, zawartych w polskim Internecie (występuje w nim raz), proponuje się wprowadzić następującą zasadę w życiu: $w$ pracy urzędnika powinno być przyjęte, że brak odpowiedzi jest decyzja (by nie marnował czasu; wtedy oczywiście trzeba też określić, jaka to jest odpowiedź). W tym też kierunku zmierza autor pewnego serwisu internetowego, podając: Brak odpowiedzi (na e-mail) oznacza, że nie ma już biletów na wybrany spektakl (występuje raz w polskim Internecie).

Raz w polskim Internecie występuje również wypowiedź: Jeśli chcesz z nami porozmawiać lub zadać pytania - pytaj bez wahania: Brak odpowiedzi nie pomoże Ci w podjęciu decyzji. ${ }^{[6]}$, która świadczy, że nawet brak odpowiedzi na niezadane pytania jest niepożądany. Warto więc zadawać pytania licząc, że uzyska się odpowiedź.

Dodatkowa trudność bierze się stąd, że jeśli przyjmie się, iż brak odpowiedzi czegoś nie oznacza (np. zgody), to wcale nie znaczy to, że oznacza coś odwrotnego (w tym przypadku niezgodę), gdyż może oznaczać coś neutralnego (np. obojętność).

\section{Bibliografia}

Austin, J. 1993. Mówienie i poznawanie (Philosophical Papers; How to Do Things with Words). Warszawa: PWN. Gleason, J.B., Raner, N.B, 2005. Psycholingwistyka. Gdańsk: Gdańskie Wydawnictwo Psychologiczne.

Habermas, J. 1997. Pojęcie racjonalności komunikacyjnej w świetle teorii aktów mowy. [W:] T. Buksiński (red.) Rozum i racjonalnść, Poznań: Wydawnictwo Naukowe Instytutu Filozofii UAM.

Nachmias, D., Frankfurt-Nachmias Ch. 2001. Metody badawcze w naukach spolecznych. Poznań: Wydawnictwo Zysk i

Nagórko A., Zarys gramatyki polskiej, Warszawa 1996.

Satkiewicz, H., Buttler, D., Kurkowska, H. 1973. Kultura języka polskiego. Warszawa: PWN.

\section{Wybrane adresy internetowe}

[1] www.astercity.net/ pawkoz/

[2] members.aol.com/jerzderwin/index17.htm

[3] http://www.krajski.com/votf.htm

[4] 217.96.166.169/uczelnia/nauka/magisteleopardl.htm

[5] zeisk.tech.us.edu.pl/ogloszenia/romanek/2_4.html

[6] www.atw.wroc.pl/link11.html 